\title{
The Social Position of the Hoplites in Classical Athens: A Historical Study
}

\author{
By Ahmed Ghanem Hafez ${ }^{*}$
}

This paper sheds light on the emergence and the growth of the Athenian hoplite class. It deals with the several types of the hoplites which the political and economic circumstances of the archaic and classical Athenian society led to their existence, such as the hoplite citizens and the farmer hoplite. I try through this paper to clarify the relation between the military role of the hoplites and their deserved social rights as citizens, in order to show their real social position in the Athenian society.

\section{Introduction}

During the time of the Greek wars in the classical period which extended from the Greek victories over the Persian Empire at the beginning of the 5th century B.C to the death of Alexander the Great in 323 B.C, many city states appeared such as Athens and Sparta which challenged the Persian hegemony. Although the warfare between these new states weakened the Greeks, it also gave them a very well - organized strong army during this period ${ }^{1}$ while those political circumstances were a significant force in strengthening the Greek army as a whole, the increasing role of the state in taking responsibility for arming and equipping its citizens was another important factor. ${ }^{2}$

We know from the Athenian constitution that the ephebes were all trained as hoplites ${ }^{3}$ and were lightly armed, and Each ephebe especially those who had reached puberty was issued with a hoplite shield and spear after the first year of their ephebian life. As a result hoplite service no longer depended on having sufficient means to buy the equipment. All Athenians, irrespective of wealth, could serve. This was the Athenian way of creating a "hoplite democracy " specially after the reforms that had been added to the ephebeia in 336 B.C. ${ }^{4}$ By the fifth century B.C. the hoplites were fighting in their own contingents with

\footnotetext{
*Associate Professor, University of Alexandria, Egypt.

${ }^{1}$ Greece was divided into hundreds of Poleis, city -states, and armed conflict between them was very common. see. Plato, Nomoi, 626A.

${ }^{2}$ Nicolas Sekunda, The Ancient Greeks: with illustrations, Osprey publishing, Oxford, 1st pub., 1986, p.1.

${ }^{3}$ The Greek word for 'weapon' is o $\pi \lambda$ ov (sing) and o $\pi \lambda \alpha$ (plu.) from the 2 nd declension neuter nouns, and so the hoplite was literally 'a man at arms '. or the heavy- armed foot soldier: see. J. F. Lazenby and David Whitehead, "The Myth of the Hoplite' Hoplon”, Classical Quarterly 46, (1996): 27-33.

${ }^{4}$ Mogens Herman Hansen, Studies in the population of Aigina, Athens and Eretria, (Denmark Det Kongelige Danske Videnskabrenes, 2006), 38; Arist., Ath.Pol.,42.3-4
} 
the light and auxiliary troops pushed to the wings as skirmishers and flank protection. This may not have been the case in the earlier periods. Homer ${ }^{1}$ and Tyrtaeus $^{2}$ presented a massed band of troops with all types of equipment fighting side by side.

Some believe that the hoplites played the central role in Greek warfare and society $^{3}$, while others have suggested that the central role carried out by other types of troops thought their role on the battlefield is usually hidden by the sources. However from what has been mentioned by Aristotle (Pol.4.10.10) we can be sure that the first body of citizens among the Greeks after the kingships was composed of warriors, initially, these were cavalrymen.

This paper will not address this line of argument, but aims instead to answer the question of whether the Athenian hoplites were considered as an important social class, It seeks to answer this question by discussing the relationship between their military role and their deserved social rights as citizens who were performing an important national public service.

The paper is divided into two main sections: the first section discusses the historical circumstances which accompanied the emergence and growth of the Athenian hoplites, while the second section discusses how the hoplite class was suffered from political and social exploitation.

\section{The Hoplites' Emergence and Growth}

There are several arguments concerning the emergence of the hoplites. One postulates a connection between the emergence of the hoplite class and that of the Topavvol, However some of these Tyrants are supposed to have seized power while occupying high ranking military offices. However, no source mentions that they succeeded in their mission with the aid of the hoplite class. According to Herodotus, Polycrates who came to power after a century and a half had established himself with a force of no more than fifteen hoplites. ${ }^{4}$ Polyaenus states that Theron had established himself as a Tyrant of Selinus with a force of three hundred slaves ${ }^{5}$, while it had been stated that

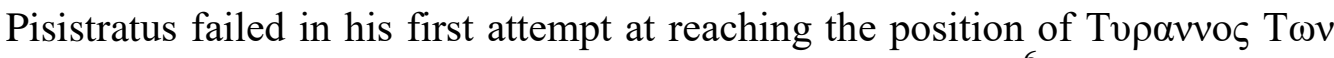
A $0 \eta v \omega v$ ca.560 B.C. With a bodyguard of fifty club-bearers ${ }^{6}$, and he managed only by depending on the Argive mercenaries. ${ }^{7}$ Aristotle also states that while the king's bodyguard consisted of citizen- soldiers, a tyrant's was composed of

\footnotetext{
${ }^{1}$ Homer, Iliad, 13. 126-34

${ }^{2}$ Tyrtaeus, Frag.11.35-38.

${ }^{3}$ Victor Davis Hanson, The Western way of war: Infantry battle in Classical Greece, Oxford university press, 2nd ed., 1989 ; The other Greeks: The family farm and the roots of Western civilizations, New York, Free press, 1995.vs Kurt A. Raaflaub and Hans Van Wees (eds.), A Compaion to Archaic Greece, Blackwell, 2013, paper back ed.

${ }^{4}$ Herodotus, 3.120 .3

${ }^{5}$ Polyaenus, Strat., 1.28.2.

${ }^{6}$ Herodotus, 1.59.5-6;Plutrachus, Sol.30;; Aristotle, AC.14.1

${ }^{7}$ Idem, 1.61.4.
} 
strangers. ${ }^{1}$ Nevertheless there are some scholars who question Aristotle's classification of the hoplites in the time of the kings and the Tyrants ${ }^{2}$.

Before democracy, the phalanxes of Athens were small, and as recorded both by Plutarch and Thucydides, the limited objectives and results of campaigns and the reliance on volunteers point to armies of hundreds rather than of thousands of hoplites. ${ }^{3}$ Because the main goal of ancient warfare was to to gain a new fertile land, some of these volunteers - who were probably non elite Athenians, were seeking to improve their personal circumstances. 4 However, while the upper class Athenians of this period were no less acquisitive than the lower class, the lower class could easily afford hoplite weapons and armour as they themselves were under a strong moral and social pressure to become soldiers. ${ }^{5}$

According to Pindar, it was through bearing difficult work, dangers, and expense in the conflict of battle or sport and specially through gaining victories that an archaic aristocrat proved his courage. ${ }^{6}$ So a majority of the Athenian hoplites probably belonged to the upper class, which on the basis of analogy with the classical period would have numbered no more than five percent of free males. ${ }^{7}$ Therefore, on many occasions, we have already seen that hoplites had fled almost even before a blow had been struck, and panic was easily communicated. Pindar says that even the sons of the gods were not immune ${ }^{8}$, and that is why it was not easy to find men who would stand when they saw part of their own army in flight. ${ }^{9}$ This may be one of the reasons why Spartans were highly successful for so long, because most of their battles were won even before they started, since their enemies feared facing them. ${ }^{10}$

In his article, Lazenby, discussed the motivations of the Spartans and all other Greeks in the battles. He believes that patriotism played an important role, as the men were clearly concerned about defending their own homes and

\footnotetext{
${ }^{1}$ Aristotle, Pol., 5.8.6.

${ }^{2}$ Jonathan M. Hall, A history of the Archaic Greek world 1200- 479BCE., 2nd ed., (Princeton Willey Blackwell, 2013), 146-7. The author pointed out that there is no direct reference in the time of kings and the Tyrants to the hoplite class

${ }^{3}$ Plutarchus, Sol.7.3; Thuc., 6.56.2,.58.1-2.

${ }^{4}$ Sara Forsdyke, Exile, Ostracism, and Democracy.The politics of expulsion in Ancient Greece, Greece, (Princeton: Princeton University Press, 2005), 139.

${ }^{5}$ Hans Van Wees, Greek warfare. Myth and Realities, (UK: Bloomsbury Academic 2004), 37 45, 55- 60.

${ }^{6}$ Pindar, Ol., 6.9.

${ }^{7}$ Hans Van Wees, War and Violence in Ancient Greece, (London: Classical press of Wales, 2009), 20; there are some scholar thinks that because of the lack of any reliable figures for calculating the relative size of the elite in this period, upper class Athenians clearly numbered close to, but less than five per-cent of the citizen body in the later fifth and early fourth centuries. see C.E. Taylor, 'A new political world', in Robin Osborne(ed.), A cultural revolution in classical Athens? Art, Literature, Philosophy, and Politics 430-380 BC., Cambridge, 2007, p.89.

${ }^{8}$ Pindar, Nem., 9.62-3.

${ }^{9}$ Xenophon, Hell., 7.5. 24.

10Plutarchus, Pel.17.6., Plutrchus mentions that the Spartans were irresistible in spirit, and because of their reputation, when they came to grips, terrifying to opponents, who themselves did not think that with equal forces they stood an equal chance with the Spartans.
} 
loved ones. ${ }^{1}$ However, I believe another motivation may have played a more important role for the other Greek hoplites and especially the Athenians. Because the poor were usually excluded from the hoplites at least in the Oligarch rule ${ }^{2}$, as they could not afford to buy the required expensive equipment, and the Athenian hoplite service was almost certainly impossible for the Thetes, who formed about 40 to 60 per-cent of the whole population of Athens, they must have had a flaming desire to keep their own wealth. This must have been a more important motivation than any other motivations ${ }^{3}$.

No doubt the emergence of the Athenian hoplites had its effects which were very clear in the break that happened with the aristocratic past, for the hoplite $\varepsilon \theta 0 \varsigma$ differed from the aristocratic. Nevertheless, hoplites remained elite, and the non- aristocratic among them adopted many aristocratic attitudes. Thucydides' Histories reflects some of these adopted attitudes, as he recorded in his work the attitude of the hoplite class when he implied that the activities of the "stone - throwers", "slingers", and archers' before a battle were of little or no importance. $4 \mathrm{He}$ commented on the 120 hoplites who perished at the hands of the Aitolian javelineers saying that "these, so many and of the same age, were the best men from the city of Athens who perished in this war".5 This seems to contain an added note of bitterness. Moreover hoplites were "the nation in armies" in states where those who could not afford such service, were excluded from full civic rights, and that was one of the important reasons for the Athenian revolutions in 411BC. As part of this revolution, it was proposed that only hoplites should participate in civic affairs. ${ }^{6}$

Finally, I must raise the idea that has been expressed recently which linked the crucial role of warfare to the constitutional development of the Greek city states. This idea can be supported by some historical events showing the socioeconomic classes which supported their preferred form of constitution, and the existence of various branches of state's military organization like horsemen $(1 \pi \pi \varepsilon 1 \varsigma)$, hoplites, light armed troops and naval crews. ${ }^{7}$

\footnotetext{
${ }^{1}$ John Lazenby, ' The Killing Zone ', in Victor Davis Hanson (ed.), Hoplites: the classical Greek battle experience, (London and New York: Rout ledge, 2003), 87-109, 105 .

${ }^{2}$ The rule in Oligarch states was that the " rich " were obliged to own weapons and train in the gymnasia, while the poor were not allowed to possess any and not to train themselves. See Arist., Pol., 1297a 29-32.

${ }^{3}$ Hans Van Wees points out that almost all arms and armour was privately owned rather than provided by the states. Only in exceptional circumstances governments might have some military equipment made at public expense or distribute some of many captured weapons as dedications. Even Aristotle in his AP recorded that by the end of the classical period, some states including Athens began to provide their citizens with arms but on regular basis . see Aristotle, Athenian constitution , 24.4. ; Hans van Wees, " Tyrants , Oligarchs , and Citizens Militias" in Angelos Chaniotis \& Pierre Ducrey (eds.),Army and Power in the Ancient word , (Stuttgart: Franz Steiner Verlag Stuttguart, 2002), 61,63.

${ }^{4}$ Thucydides, 6.69.2.

${ }^{5}$ Idem., 3.89.4

${ }^{6}$ Idem, 8.65.3, 97.1, Aristotle, Pol.1279a 37ff., 1297b lff.

${ }^{7}$ Vincent Gabrielsen, 'Socio- economic Classes and Ancient Greek warfare ', In Karen Ascar \& \& Jens Erik skydsgaard(eds.), Ancient History matters: Studies presented to Jens Erik Skydsgaard on his Seventieth birthday, L'Erma di Bretschneider, Analecta Romana Instituti Danici, suppl.xxx, Academia di Danimarca, Roma, 2002, 203- 220, 203-4.
} 
The last view is chiefly predicated on many notions claimed by the classical sources to have been widely held in the Greek world. The first notion is that the level of personal economic ability was the factor deciding the branch within which the individual had to fight. The second notion is that the currently prevalent mode of warfare determined which of these branches and the social classes which they represented were regarded as the ones of paramount military significance. The third and last notion is that the population groups included in the military deserved to be rewarded with political privileges. All these notions support the idea of a relationship between warfare and constitutional developments. They also reflect the influence of warfare on the composition of the ancient Greek armed forces. Here Aristotle tells us that "the very first political organization consisted of the horsemen because of their strength and superiority in warfare and the hoplites were useless without tactical system " $\sigma v v \tau \alpha \xi \varepsilon 1 \alpha$ "and since an understanding of formation " $\tau \alpha \xi 1 \varsigma$ " did not exist at such early time, but as poleis grew and the hoplites became stronger, then more people were allowed to enjoy citizen status". .

Here I would like to comment on what had been mentioned by Aristotle concerning the uselessness of the hoplites without organization and their lack of experience in military affairs. We can better understand Aristotle's analysis in the light of the Athenian commitment to build and maintain a massive war fleet which made military service available for the majority of the citizens who were too poor to be hoplites.

Aristotle and Plutarch described the military activities of those sub hoplite citizens and the lower class hoplite, which were made much easier by the introduction of the military pay ${ }^{2}$, while hoplites began to be paid too, in 450 BC. and even earlier, When pay was introduced for both the jurors and the councilors of Athens ${ }^{3}$, but after the reforms of Cleisthenes fighting either as a hoplite or a sailor became a normal experience of many numbers of the poor Athenians.

\section{The Hoplite Class between the Political and Social Usage}

Snodgrass considered the evolution of hoplite tactics and the hoplite phalanx as one of the most important developments of the archaic age and one of the most significant changes to solidify the polis form. His theory is based

\footnotetext{
${ }^{1}$ Arist. Pol., 1297b 16-28; when Cleisthenes introduced his political reforms in Athens circa $508 / 7$, he extended citizenship to many foreign immigrants and slaves in order to expand the number of hoplite infantry to nine thousand. Arist. Pol.3.1.10, and after the Persian war Athens emerged as one of the leading states of Greece, and policy toward citizenship became much more restrictive, This can be seen most clearly in Pericles' law of $451 / 0$ which restricted citizenship to those born to Athenian parents. Arist.Ath.Pol.26.4.; Brian Cambell \& Lawrence A.Tritle (eds.), The Oxford Handbook of Warfare in the Classical World, (Oxford: Oxford University Press, 2013), 212.

${ }^{2}$ Arist., Ath. Pol., 23.1.;Plut.Cim.,9.4;Them.10.4.where they both indicate that the military

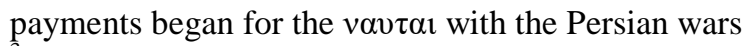

${ }^{3}$ Arist.,Ath.Pol., 27. 3-4.; Plat.Grg.,515e.
} 
on what had marked the hoplite phalanx a superior technique of war and its inclusion of the aristocratic elites 1, who could no longer win battles using their traditional methods, but required the service of the hoplite infantry. This situation would have given the hoplite class a bargaining position from which to secure greater rights of citizenship ${ }^{2}$.

Hoplite' equipment was gradually increased and was used in warfare by individual aristocrats a long time before there was a convenient political cohesion to give the hoplite phalanx aid Here, I think it may be helpful to remember that the full hoplite panoply didn't exist earlier than 700 B.C, as the full hoplite panoply was not seen until it appeared on a vase dated around 675 and an actual hoplite phalanx appears first to the knowledge on a vase dated about $650 .^{3}$

As the Athenian phalanx was a remarkable form in most of the Greek armies $^{4}$, it relied on the horsemen (the cavalry), and as previously mentioned on both the hoplites and the farmer hoplites (the poor) as we have been told by Hanson, who insisted that the classical hoplite phalanx, especially that of Athens, was an artificial reflection of the polis itself ${ }^{5}$. Although the Athenian phalanx included the poor farmers, they were of great importance for the whole formation because farmers became increasingly influential in early Greek communities. They managed to impose their custom of both co-operation and egalitarianism on the phalanx giving it good order " $\varepsilon v \tau \alpha \xi \varepsilon 1 \alpha$ "6 .

These farmer hoplites were able to obtain social importance and political influence compared with the poorest elements of the Athenian community ${ }^{7}$ who remained sidelined and according to what has been quoted above from Aristotle (p.4), it is clear that the concept of citizenship emerged as an

\footnotetext{
${ }^{1}$ Anthony M. Snodgrass, Arms and Armor of the Greeks, (Baltimore, MD: John Hopkins University Press, 1967), 51, 110.

${ }^{2}$ Arist., Ath.Pol.5.3;Pol.1296a19; Plut.,Sol.,14.1; Joseph A. Almeida, Justice as an aspect of the polis idea in Solon' political poems: A reading of the Fragments in light of the researches of new classical Archaeology, (Leiden, the Netherlands: Brill, 2003) 171- 3.

${ }^{3}$ Raphael Sealey, A History of the Greek City States.ca700-338B.C., (Berkeley: University of California Press, 1967), 30.

${ }^{4}$ About the relationship between the Capitalism and the Democracy in the Athenian society and how the reforms of both Solon and Cleisthenes affected the formation of the Athenian phalanx. see. George E. McCarthy, Classical Horizons : the origins of sociology in Ancient Greece, (Albany NY: State university of New York Press, 2003), 72-77.

${ }^{5}$ Victor Davis Hanson points out that as the polis grew larger and richer, phalanxes incorporated more hoplites, and in response to these changes, warfare became more complex, with greater use of maneuvers, as armament, after produced in " factories " by the state, grew somewhat lighter and thus perhaps cheaper as well. Victor Davis Hanson, the Western way of war: infantry battle in classical Greece: with a new preface, (USA: University of California press, 2009), xxxiv.

${ }^{6}$ According to Jason Crowley, within the norms and values of Athenian society, combat held a special place. For Athenian men, to fight was laudable, to kill was praiseworthy, and to be killed while doing so was the most honorable way to die . Jason Crowley, the Psychology of the Athenian hoplite: the culture of combat in Classical Athens, (Cambridge: Cambridge University Press, 2012), 96.; Louis Rawlings, The Ancient Greeks at War, (Manchester: Manchester University Press, 2007), 52-59.

${ }^{7}$ Victor Davis Hansen, Warfare and Agriculture in Classical Greece, (California: University of of California Press, 1998), 239.
} 
articulation of political, social, religious and economic rights and privileges of these farmers. If farmers from the Archaic period to the Classical time gave the Athenian phalanx a concept of good order, it was not in the creation of neat rows and files of hoplites that excluded those who were socially and politically marginalized, nor was the excuse of equipment considered a convincing reason to prohibit the hoplites from fighting in a fluid or individualistic manner. ${ }^{1}$

In fact, the difference in equipment between the poorest hoplites and the light infantry is not very clear, perhaps more significant was the intention to stand one's ground for the sake of the community and for the farm, perhaps to engage enemies in very close combat rather than skulking outside the range of missiles' or, like light infantry, relying on employing them in combat and running for it when the enemy came very close. This can provide a very logical explanation for the Greek mercenaries of Psmmetichus 664-610BC. ${ }^{2}$ And those Athenian metics ${ }^{3}$, who were found in the service of other countries or states, had clearly been disconnected from their homeland and outsiders in their new places. However they could also fight bravely and successfully as hoplites attempting to make new lives for themselves.

Although many factors could affect how courageously hoplites performed in battle, morals were naturally a critical factor. The Athenian hoplite forces tended to enjoy a high degree of cohesion, although they were not entirely homogenous socially; relative degrees of wealth were sometimes evident. ${ }^{4}$ The fact that they constituted an elite group within the city securing solidarity is evidenced by fact that the Athenian hoplites fought in the company of their fellow tribesmen, with whom they often had ties either of friendship or blood. These ties obligated them to follow them in the ranks ${ }^{5}$.

\footnotetext{
${ }^{1}$ Donald Kagan and Gregory F. Viaggiano, "The Hoplite debate" In Men of Bronze: Hoplite warfare in Ancient Greece, ed. D. Kagan and Viaggiano. (Princeton: Princeton university Press, 2013), 1-57, 28-35; about the phenomenon of escaping the farmer soldiers of fortune from the framework.see: John R. Hall, "Not Patriots, Not Farmers,Not Amateurs: Greek Soldiers of fortune and the Origins of the Hoplite Warfa" in Men of Bronze: Hoplite Warfare in ancient Greece, ed. Donald Kagan and Gregory F. Viaggiano, (Princeton: Princeton University Press, 2013), 176-193, 182.

${ }^{2}$ Diod.Sic.,1.66.8; Adrian Kerr, Ancient Egypt and Us: The Impact of Ancient Egypt on the Modern World, (USA: Ferniehirst Publishing, 2009), 17; Michael Sage, Warfare in Ancient Greece. A source book, (UK: Taylor \& Francis Ltd, 2002), 150; Anne Burton, Diodorus Siculus Book 1. A Commentary, Brill, 1972, p.200.

${ }^{3}$ Christopher Carey, Trials from Classical Athens, Rout ledge, 2012, p.10; about the definition of the metics and the metic' tax. See Douglas M. Macdowell, The Law in Classical Athens: Aspects of Greek and Roman Life, Cornell university press, Thames and Hudson,1978, pp.778; and about the status of the metics in general.see. Elizabeth A. Meyer, Metics and the Athenian Phialai- Inscriptions: A Study in Athenian Epigraphy and Law, Steiner, 2010, about the metic women and they could not become women priests in Athens. See. Matthew Dillon, Girls and Women in Classical Greek Religion, Routledge, 2013,p.205

${ }^{4}$ Robert J. Littman, Kinship and Politics in Athens 600-400B.C., 1990, p.87; Anthony J. Podlecki \& A. James Holladay, Athens in the fifth century and other studies in Greek History, Ares publishers, 2002, p.67.

${ }^{5}$ Edward E. Cohen, The Athenian Nation, Princeton university press, 2000, p.104-29; Matthew Robert Christ, The Bad citizens in classical Athens, Cambridge university press, 2006, p.99.
} 
Some scholars think that it could be helpful in studying the social position of the Athenian hoplites in the classical period, to assume that the poorer Athenian citizen was free to choose between serving and not serving and to be maintained by the state if he chose to serve. Whereas the wealthier Athenian citizen was not free in this sphere ${ }^{1}$. Here it is worth nothing that although all citizens - hoplites were ideologically equal, some factors led to what can be called "the over- representation" of some groups of people in the ranks. For example, in the 5th century B.C. all hoplites had to provide their equipment, which may have disadvantaged those with fewer resources.

Later the state in the 4th century began sometimes providing a shield and a spear to all new recruits ${ }^{2}$. Moreover, in the mid-fourth century BC. Other changes had occurred in the process of drafting hoplites, where it was up to the generals ( $\sigma \tau \rho \alpha \tau \eta \gamma o \imath)$ to select recruits from each of the city's ten tribes, and they were drawing their names in from draft lists known as katalogoi. ${ }^{3}$ There were some citizens to be exempted from conscription such as:

1. Those who are over the age of fifty nine $e^{4}$

2. Those who were still serving in the boule or in major positions ${ }^{5}$.

3. Those who were serving in the chorus of the dramatic festivals ${ }^{6}$

4. The ill and disabled.

Exemption of the first three categories no doubt indicates the importance of their current role by which they could emphasize their civic identity and rights the military service was a national duty, and whoever thought about avoiding or deserting the battlefield, he could be charged with a public law suit graphe astrateias ${ }^{7}$ or the graphe lipotaxiou ${ }^{8}$. The punishment for any one being being convicted was known as the atimia $\left(\alpha \tau \mu \mu^{\alpha} \alpha\right)^{9}$.

It is very clear that the Athenian democracy in the fourth century was inclusive in that even slaves and the "non - citizens "shared in the democratic polis, while in the fifth century it appears to have been exclusive because not all the citizens were equal participants in the social, economic, and political life of the city. ${ }^{10}$ But Hesk thinks that from the mid-fifth century onwards, more than half of the male citizen population of Attica had the economic status of a

\footnotetext{
${ }^{1}$ Nicolas Sekunda, Greek Hoplite 480-323B.C.,Osprey Publications, U.K., 2005, p.19

${ }^{2}$ Arist. Ath.Pol. 42.4 .

${ }^{3}$ In Classical Athens, It maintained that both the middling farm owner (yeoman) and the radical Athenian democrat were recognizable each by his membership of one of the four Solonian property classes, the hoplites are the Zeugitae, the poor crewmen the thetes. About the importance of the Katalogoi and their uses.see Debra Hamel, Athenian Generals: Military authority in the Classical period, ( Leiden: Brill, 1998), 24.

${ }^{4}$ Arist. Ath.Pol. 53.4.

${ }^{5}$ Lycurgus, 1.37 .

${ }^{6}$ Demosthenes, 21.15 .

${ }^{7}$ Lysias, 15; Demosthenes, 59.27

${ }^{8}$ Lysias, 14.

${ }^{9}$ Andocides, 1.74; Aeschenes, 3.176.

${ }^{10}$ Deborah Kamen, op. cit., p.113.
} 
hoplite. Many thetes became hoplites in his opinion because of the increasing prosperity in the mid-fifth century.

Here one should inquire: If it is indisputable that the fifth century Athenian empire derived its growth and security from a powerful navy rather than from its hoplites. Then why did the Athenians enroll such great numbers of hoplites (rich / poor)?

Hesk proposes that the Athenian political discourse tended to encourage and support hoplite identity to use it against the poorer rowing class, as it was clear that to be a hoplite means to be part of the middle class, whose property and strength in numbers made them a dominant social group in Athens ${ }^{1}$. Such domination can be recognized if we focus on a certain right they had acquired, the ostracism, which had been mentioned by Aristotle where he indicated that the first ostracism took place in 488. He linked this event to the success of the Athenian hoplites at Marathon 490 (Ath.Pol., 22) Encouraged by their victory, and being aware of having saved the city-states and the Greeks in general, the citizen hoplites, and probably the entire set of citizens, who had a very little access to the magistracies despite Cleisthenes' reforms, they used their right of ostracism $^{2}$.

\section{Conclusion}

The hoplites formed a very important group during the history of the Athenian society till the classical era. Their importance increased due to several political circumstances, and that is why they managed to fix their position as a social class regardless of their economic qualifications or wealth by the grace of Cleisthenes's reforms, which Cleisthenes developed and introduced after $508 / 7^{3}$. These reforms, as D. Pirtchard points out, effectively integrated Athens for the first time. Each free male of Attica was now registered as a citizen of Athens in his local deme and groups of these villages and suburbs from across Athenian territory were linked together in ten tribes, which served as subdivisions of the new popular council and controlled army of hoplites ${ }^{4}$.

The New registers of citizens in the demes were used to conscript hoplites for each tribal crops. This was the city's first mechanism for the standard way of raising hoplites until the second quarter of the fourth century ${ }^{5}$.

\footnotetext{
${ }^{1}$ John Hesk, Deception and Democracy in Classical Athens, (Cambridge: Cambridge University Press, 2000), 24.

${ }^{2}$ Maurice Sartre, Histoires Grecques: Snapshots from Antiquity, trans. Catherine Porter, (Massachusetts: Harvard University Press, 2009), 83.

${ }^{3}$ Aristotle , Ath. Pol., 20-1 ; Hdt.5.66-73.

${ }^{4}$ David M. Pritchard, " The Symbiosis between democracy and war : the case of ancient Athens", in War, Democracy and Culture in Classical Athens, ed. David M. Pritchard, (Cambridge: Cambridge University Press, 2010), 1-62, 15.

${ }^{5}$ About the reorganization of the Athenian army in Cleisthenes's reform. see: Everett L. Wheeler, "The General as Hoplite", in Hoplites the Classical Greek battle experience, ed. Victor Davis Hanson, ( New York: Routledge , 2002), 121-172, 135 where she discusses role
} 
Although they were very aware of the nature of their role and its importance to the city of Athens and to its consequent political systems, they did their best to prove themselves as good brave soldier-citizens in many battlefields.

The social position of the poor farmers gradually developed especially after the poor farmers were allowed to join the Athenian phalanx, and the city of Athens began to provide both equipment and payment as well. They could improve their role through their morals within their national services, especially their cohesion

I think that both Athenian military ambition and all of the political conflicts served to increase the social position of the Athenian hoplites, because even when Athens created democracy and adopted it, the hoplites both the rich and poor could improve their social position especially when they were permitted to practice the right of the ostracism by the grace of Cleisthenes's reforms .This may indicate the role of democracy in creating a new historical, social, and political status in the Athenian society .

Finally I believe that the Athenian society in the classical era can be considered an ideal society for dealing with such a class. Although the hoplite first marginalized for a very long time, the military classification of the classical Athenian hoplite which was based on his economic potential and controlled his social position later, and the official sponsorship of the city state for its hoplites, has been adopted by many of the modern states as they believed in the efficiency of the classical Athenian thought in this field.

\section{Bibliography}

Aeschenes, L.C.L.

Andocides , L.C.L.

Aristotle, Athenian Constitution, L.C.L

------, Politics, L.C.L

Demosthenes, L.C.L

Diodorus Siculus , L.C.L.

Herodotus, Histories, L.C.L.

Homer, Iliad, L.C.L.

Lycurgus, L.C.L

Lysias, L.C.L.

Pindar, Nemesis, L.C.L.

Plutarchus, Vitae, L.C.L.

Polyaenus, L.C.L.

Plato, Laws, L.C.L

----- , Gorgias , L.C.L.

Thucydides, Histories, L.C.L.

Tyrtaeus, Fragments, L.C.L.

Xenophon, Hellenica, L.C.L.

of the Zeugitai class in the Athenian army and had known with the term "middle - class hoplites". 
Almeida, J. A. "Justice as an Aspect of the Polis idea in Solon's Political poems", A reading of the Fragments in the light of the researches of New Classical Archaeology. Leiden: Brill, 2000.

Burton, A. Diodorus Siculus Book 1. A Commentary. Leiden: Brill, 1972.

Cambell, B. and A. L. Tritle (eds.), The Oxford Handbook of warfare in the Classical World. Oxford: Oxford University Press, 2013.

Carey, C. Trials from Classical Athens. New York: Routledge, 2012.

Christ, M. A. The Bad Citizens in Classical Athens. Cambridge: Cambridge University Press, 2006.

Cohen, E. E. The Athenian Nation. Princeton: Princeton University Press, 2000.

Crowley J. The Psychology of the Athenian Hoplite: The Culture of Combat inClassical Athens. Cambridge; New York: Cambridge University Press, 2012.

Dillon, M. Girls and Women in Classical Greek Religion. London \& New York: Routledge 2013.

Forsdyke, S. Exile, Ostracism, and Democracy. The Politics of expulsion in Ancient Greece. Princeton: Princeton University Press, 2005.

Gabrielsen, V. " Socio-economic Classes and Ancient Greek warfare." In Ancient History matters: Studies presented to Jens Erik Skydsgaard on his Seventieth Birthday 2002, edited by K. Ascar and J. E. Skydsgaard. L'Erma di Bretschneider, Analecta Romana Instituti Danici, Supp.XXX, Academia di Danimarca / Roma , 2002

Hall, Jonathan M. A History of the Archaic Greek World 1200-479BCE. Oxford: Wiley, Blackwell 2013.

Hall, Jonathan M. "Not Patriots, Not Farmers, Not Amateurs: Greek soldiers of Fortune and the origins of the Hoplite warfare". In Men of Bronze: Hoplite Warfare in Ancient Greece, edited by D. Kagan and G.F. Viaggiano. Princeton: Princeton University Press, 2013.

Hamel, D. Athenian Generals: Military authority in the Classical Period. Leiden, Boston, Koln: Brill, 1998.

Hanson, Victor Davis. The Western way of war: Infantry battle in Classical Greece. Oxford: Oxford University Press, 1989.

Hanson, Victor Davis. The Other Greeks: The family farm and the roots of western civilizations, New York: The Free Press, 1995.

Hansen, Mogens Herman. Studies in the population of Aigina, Athens and Eretria: Copenhagen : Det Kongelige Danske Videnskabernes Selskab, 2006.

Hasting, J, Encyclopedia of Religion and Ethics. New York: Scribner. 1951.

Hesk, Jon. Deception and Democracy in Classical Athens. Cambridge: Cambridge University Press, 2000.

Kagan D. and G. F. Viaggiano. "The Hoplite debate". In Men of Bronze: Hoplite warfare in Ancient Greece, edited by Kagan D. \& Viaggiano. Princeton: Princeton University Press, 2013.

Kamen, D. Status in Classical Athens. Princeton: Princeton university press, 2013.

Kerr, Adrian. Ancient Egypt and Us: The impact of Ancient Egypt on the modern world. USA: Ferniehirst publishing, 2009.

Lazenbay, J.F. and David Whitehead. "The Myth of the Hoplite'Hoplon", Classical Quarterly 46 (1996): 27-33.

Lazenbay J.F. "The Killing Zone". In Hoplites: The Classical Greek battle experience, edited by V.D Hanson. London and New York: Routledge. 2003

Liddell, P.P. Civic Obligation and Individual Liberty in Ancient Athens. Oxford: Oxford University Press, 2007. 
Littman, R.J. Kinship and Politics in Athens 600-400B.C. Oxford: Oxford University Press, 1990.

MacDowell, D.M. The Law in Classical Athens: Aspects of Greek and Roman Life. Ithaca, NY: Cornell University Press, 1978.

McCarthy G. E. Classical Horizons: the origins of sociology in Ancient Greece. Albany NY: State university of New York Press, 2003.

Meyer E.A. Metics and the Athenian Phialai - Inscriptions: A Study in Athenian Epigraphy and Law. Stuttgart: Franz Steiner. 2010.

Papakonstantinou, Zinon. Sport in the Cultures of the Ancient World: New perspectives. London: Routledge, 2013.

Podlecki, A. and J. Holladay. Athens in the Fifth century and other studies in Greek History. Chicago, IL: Ares Publishers, 2002.

Pritchard, D. M. "The Symbiosis between democracy and war: the case of ancient Athens". In War, Democracy and Culture in Classical Athens edited by David M. Pritchard. Cambridge, Cambridge University Press, 2010.

Raaflaub, K.A. and H. V. Wees. A Companion to Archaic Greece. Malden \& Oxford: Blackwell, 2013.

Rawlings, Louis. The Ancient Greeks at War Manchester: Manchester University Press, 2007.

Robinson, E.W. Ancient Greek Democracy: reading and sources. Malden \& Oxford: Blackwell, 2008.

Roselli, D.K. Theater of the people: spectators and the society in Ancient Athens. Austin: University of Texas Press, 2011.

Sage, Michael. Warfare in Ancient Greece. A Source book. London: Taylor and Francis Ltd, 2002.

Salmon, J. and L. Foxhall. When men were men: Masculinity, Power, and Identity in Classical Antiquity. London: Routldge, 2013.

Sartre, M., Histoires Grecque: Snapshots from Antiquity. Massachusetts: Harvard university Press(in French), 2009

Sealey, R., A History of the Greek City -State ca.700-338 B.C. Berkeley: University of California Press, 1967.

Sekunda, N. The Ancient Greeks: with illustrations. Oxford: Osprey publishing, 1986.

Sekunda, N., Greek Hoplite 480-323B.C. Oxford: Osprey publishing, 2005.

Snodgrass, A.M. Arms and Armor of the Greeks. Baltimore, MD: John Hopkins University Press, 1967.

Taylor, C.E., "A New Political World”. In A Cultural Revolution in Classical Athens? Art, Literature, Philosophy and Politics 430-380B.C edited by Osborne R. Cambridge: Cambridge University Press, 2007.

Wess, H.V., War and Violence in Ancient Greece. London: Classical Press of Wales, 2009.

Wess, H.V. Greek warfare. Myths and Realities. UK: Bloomsbury Academic. 2004.

Wess, H.V. "Tyrants, Oligarchs, and Citizens Militias". In Army and Power in the Ancient word, edited by Angelos Chaniotis and Pierre Ducrey. Stuttgart: Franz Steiner Verlag Stuttguart, 2002.

Wheeler, E. L. "The General as Hoplite". In Hoplites the Classical Greek battle experience, edited by Victor Davis Hanson. New York: Routledge, 2002. 